\title{
Da (im)probabilidade de ser imigrante: uma leitura discursiva de "negro" $e$ "branco" em sintagmas nominais num corpus do português
}

Phellipe Marcel da Silva Esteves ${ }^{a}$

\begin{abstract}
Resumo
Neste artigo, inscrito no aparato teórico da Análise do Discurso materialista (Pêcheux), pretendemos investigar como o estatuto de "imigrante" no Brasil vai sendo construído pela língua que se fala no país, e permitindo que a alguns sujeitos essa designação seja aceitável e a outros seja vetada. Para cumprirmos este propósito, nos debruçamos sobre as oposições / complementaridades / combinações dos nomes "escravo", "colono", "colonizador", "senhor de engenho", "imigrante" com os adjetivos "branco", "negro", "africano", "europeu" e respectivas flexões no feminino e no plural, fazendo uso da primeira versão do Corpus do Português organizado pelos pesquisadores Mark Davies e Michael J. Ferreira. Com isso, por um lado, foi necessário também refletir sobre como a Análise do Discurso pode se articular com a Linguística de córpus. Por outro, fomos chegando a proveitosos resultados que não remetem diretamente à imigração, mas que dizem muito sobre como colonos, colonizadores e senhores de engenho são significados em distintas materialidades.
\end{abstract}

Palavras-chave: Questão étnico-racial. Escravidão. Imigração. Discurso. Política.

Recebido em 13 de janeiro de 2017 Aceito em 09 de maio de 2017 


\section{Das motivações e problemas}

O povo que escreve sobre si é determinado por aquilo que ele mesmo exclui. (CERTEAU; DOMINIQUE; REVEL, 2002 [1975], p. 176; tradução nossa) ${ }^{1}$

Escrever em uma língua sobre seu povo, sobre os corpos humanos que habitam essa língua, sobre as paisagens que a distinguem doutras línguas, sobre a formação de subjetividades nela significa tomar partido. E é uma tomada de partido, é um posicionamento político. Se, conforme nossa epígrafe, somos determinados por aquilo que excluímos em nossa escrita, é necessário pensar que povos, que corpos, que paisagens, que subjetividades excluímos nessa escrita, e que outros nela inscrevemos. Como significamos os sujeitos nas línguas através dos processos discursivos nelas engendrados é um gesto político. Neste artigo pretendemos, por isso, entender de que modo referentes discursivos como "imigrante" e "negro" vão se distanciando na língua, de modo a, praticamente, se anularem semanticamente.

Com Orlandi (2002, p. 95ss), consideramos que as políticas de língua - que a autora diferencia de política linguística - são práticas de legislar, determinar, cercear, silenciar e reconhecer as línguas nos espaços dos Estados, de modo que há instituições responsáveis por essa regulação/regulamentação, e também há uma reprodução de valores, como a diversidade linguística, circulantes entre os sujeitos que se inscrevem numa ou em mais línguas. Pensamos, assim, a própria escrita - principalmente antes do século $X X$, quando se dá uma aceleração no processo de alfabetização no Brasil - como um lugar, um dispositivo, em que as políticas de língua se desenvolvem, por registrarem decisões e tomadas de posição sobre a língua que reverberam na memória discursiva e por materializarem, no caso deste artigo, predicações/qualificações/ adjetivações em determinados sintagmas nominais.

Visamos compreender como, com esse funcionamento gramatical de modificação de núcleos de sintagmas nominais com adjetivos, ao longo da história do Brasil, o discurso sobre imigração foi tirando a possibilidade de se falar de "imigrante

${ }^{1}$ Original: "Le peuple qui s'écrit se détermine parce qu'il exclut" (CERTEAU ; DOMINIQUE ; REVEL, 2002 [1975], p. 176). negro", enquanto se privilegia dizer "imigrante branco" e "imigrante europeu". Ao mesmo tempo, vão-se significando, mutuamente, "escravo" e "negro". Para cumprirmos 
2 Para maior familiarização com os termos, aqui usaremos versões transliteradas dos nomes dos conceitos: córpus, no singular; córpora, no plural.

${ }^{3}$ Disponível em http:// corpusbrasileiro.pucsp br, com acesso integral pago.

${ }^{4}$ Ainda não disponível para consulta. esse propósito, nos debruçamos sobre as oposições / complementaridades / combinações dos nomes "escravo", "colono", "colonizador", "senhor-de-engenho", "imigrante" com os adjetivos "branco", "negro", "africano", "europeu" e respectivas flexões no feminino e no plural, fazendo uso da primeira versão do Corpus do Português organizado pelos pesquisadores Mark Davies e Michael J. Ferreira, e lançado numa plataforma digital da estadunidense Brigham Young University (DAVIES; FERREIRA, 2006). A ferramenta virtual permite uma contagem de ocorrência das palavras pesquisadas, bem como a leitura de sequências - resumidas ou ampliadas, a depender da interação do pesquisador donde elas foram extraídas.

O referido cór pus ${ }^{2}$ conta com um total de 45 milhões de palavras coletadas em documentos acadêmicos, literários, orais e jornalísticos brasileiros e portugueses, em materialidades que abrangem dos anos 1200 aos 1900. Conforme relata Oliveira (2009), ainda não há córpora brasileiros longos consolidados e feitos por brasileiros, apesar de tentativas como o Corpus Brasileiro, da PUC-SP, ${ }^{3}$ e o Corpobras, da PUC-Rio. ${ }^{4}$ Daí termos escolhido a primeira versão - mais reduzida, mas com os textos que nos interessavam, escritos e impressos, não digitais - do córpus compilado por Davies e Ferreira. Nessa escrita, que consideramos um dispositivo em que vão se constituindo os sentidos sobre aquilo que é negro e aquilo que é branco na formação social brasileira, somos confrontados com sintagmas com a mesma forma - como "imigrante branco", por exemplo -, mas inscritos em distintas formações discursivas. Segundo Pêcheux,

(...) o funcionamento dos elementos lógico-linguísticos de um enunciado depende das formações discursivas no interior das quais cada um desses elementos pode tomar um "sentido", de modo que, em última instância, será a configuração das formações discursivas no interior das quais se inscreve uma subjetividade dada que determinará $o$ "sentido" que esse enunciado tomará com o caráter necessário ou contingente, disjunto ou integrado etc., dos objetos e propriedades que nele se manifestam (PÊCHEUX, 2009 [1975], p. 207)

Assim, ainda que os sintagmas encontrados possuam a mesma forma material, eles são significados a depender 
da formação discursiva em que se inscrevem e de onde o leitor interpreta. Tomando isso como primado, olharemos para as sequências que traremos à frente não apenas como ocorrência de palavras repetidas, mas como sintagmas que projetam efeitos de sentido sobre os "objetos" - e sujeitos como "escravo", "colono", "colonizador", "senhor-de-engenho" e "imigrante" - e suas propriedades - como "negro", "branco", "africano", "europeu". Para tal, nos perguntamos, por exemplo, como o processo de adjetivação, em sua repetição, pode ir inchando os objetos/sujeitos com propriedades que passam a fazer parte deles, de modo que os efeitos de sentido passem a ser dominantes em diversas formações discursivas, transversalmente.

Antes de entrarmos na discussão sobre a adjetivação e também sobre a utilização de um córpus, uma ressalva: não buscamos sintagmas nominais com os adjetivos "índio" ou "indígena" no Corpus do português porque nosso foco está no contraste da relação entre negros e brancos, culminando nos processos que rendem efeitos de sentido a "imigrante". Entretanto, como córpus secundário, fora do Corpus do português supramencionado, selecionamos a Encyclopédia popular de 1879, uma das primeiras obras de divulgação científica no Brasil. Nela, fizemos a busca do nome "escravo" acompanhado por adjetivo, e a única referência à etnia, cor e origem materializava esse adjetivo:

S1: Em começo do século XVII, a escravidão dos indios foi causa de renhida luta erguida entre os jesuitas e os colonos (...) A cidade do Rio de Janeiro offerecia então o espectáculo de um grande mercado de escravos indios, que erão para alli conduzidos principalmente pelos sertanejos de S Paulo" (VEIGA, 1879, p. 555; destaques nossos)

Note-se: (a) a materialização adjetiva de quem eram os "escravos" (índios), mas (b) a vacância adjetiva de quem eram os "colonos" (Ø), tampouco os "sertanejos". É com regularidades desse tipo, mas marcando também o adjetivo "negro", que trabalhamos neste artigo, no sentido de observar como a língua, em sua lógica de atribuição de propriedades, vai fixando-as nos nomes, a tal ponto que o substantivo "escravo" pode ser retomado anaforicamente por "negro", na melhor das hipóteses. Extraímos, à frente, uma sequência com esse funcionamento do Corpus do português, em que não consta 
adjetivação nem de "escravo" nem de "colonizador", mas em que há uma retomada de "escravo" por "negro":

S2: (...) o escravo era a peça chave do esquema produtivo; podiam ser divididos entre os domésticos que trabalhavam diretamente para a camada senhorial e os que trabalhavam nas atividades produtivas da lavoura. Os primeiros serviam como cozinheiras, amas-de-leite, costureiras, etc. Durante todo o período colonial esta camada, ao contrário do que se pensa, exercia atitudes de rebeldia, é o caso dos quilombos (agrupamentos formados por negros fugitivos) como o de Palmares. A colonização do Brasil foi feita com base no colonizador que para cá veio sem família, portanto na colônia havia uma escassez de mulheres brancas. A presença de mulheres índias e negras facilitam portanto a mestiçagem, uma das características desta sociedade. Havia ainda outras camadas sociais; é o caso do setor mercantil, geralmente na mão dos portugueses. Era uma sociedade que dava poucas oportunidades ao trabalho livre. O trabalho com as mãos de uma forma geral era considerado coisa de escravo e, portanto, extremamente desvalorizado. (In: Sociedade do Período Colonial no Brasil)

Logo de início, notemos a retomada de "escravo" por "negros fugitivos". Depois, perguntemo-nos sobre a adjetivação: em que ela consiste, e como trabalhar com ela? Revendo as considerações de Dubois (1994 [1969]) sobre a importância dos sintagmas nominais, em detrimento dos verbos, numa análise de enunciados, encontramos:

(...) o sintagma nominal no sentido lato é o constituinte fundamental, o que vai permitir aplicar certas metodologias. A oposição feita entre as formas do singular e do plural, entre as palavras acompanhadas de tal ou tal adjetivo, as palavras das quais se diz alguma coisa são, vê-se, unidades muito claramente diferentes das que podem formar o léxico no modelo de competência, de regras que presidem à definição dos morfemas. (DUBOIS, 1994 [1969], p. 107)

Não estamos completamente de acordo em rebaixar os verbos em privilégio dos sintagmas nominais - até porque, para isso, seria necessário nos debruçar sobre o modo de organização de muitas línguas, e sua relação com os discursos produzidos nessas línguas -, mas tomamos emprestado do autor o procedimento analítico: mostrar as diferenças, em termos de efeito de sentido, do acompanhamento ou não de um sintagma nominal por um adjetivo. Para nós, a adjetivação é um modo de saturar os sentidos do substantivo, que vai sendo 
significado pelo modo como é caracterizado discursivamente, a tal ponto que o adjetivo se torna desnecessário: ele se torna um efeito de sentido do nome em seu silêncio, de modo que o adjetivo, em sua falta, seja a evidência que não precisa ser dita. Ao mesmo tempo, o adjetivo, se metalexicalizado como substantivo - caso, por exemplo, dos adjetivos "negro", "branco", bem como "africano" e "europeu" - também vai sendo preenchido pelos sentidos do substantivo que qualifica, de modo que algo de "escravo" sobrevive em "negro", mas que "branco" não seja prenhe de sentidos de colono ou colonizador, ou mesmo explorador.

Daí que é possível apontar uma glosa de contrariedade de pensamento na S2 acima - "ao contrário do que se pensa" -, uma "não coincidência do discurso consigo mesmo, constitutivamente afetado pelo jogo em si mesmo de outros discursos" (AUTHIER-REVUZ, 1994, p. 255), em relação a "esta camada" (também em relação parafrástica com "escravo" e "negros fugidos". Formula-se discurso sobre a índole do escravizado, de modo que haja discursos em choque. No entanto, as violências cometidas não encetam discurso polêmico ou alguma não coincidência entre dois discursos. Nem mesmo se menciona que se pensa algo sobre a mestiçagem no Brasil: teria sido a escassez de mulheres brancas e a presença de mulheres índias e negras que levariam à mestiçagem. Sem violência. Sem estupro. Sem conflito. Escravos e negros são rebeldes, apesar de se pensar o contrário. Colonizadores teriam uma prole mestiça no Brasil. Sem rebeldia.

Este estudo pode representar um avanço em termos de dispositivo analítico da Análise do Discurso. Podemos, com ele, nos questionar sobre o funcionamento da qualificação/ modificação/adjunção adjetiva propriamente dita. Se é válido afirmarmos, discursivamente, que às vezes um adjetivo é materializado, porque ele é necessário para promover um efeito de sentido insuspeito para determinado substantivo - caso de "escravo branco" -, o que dizer quando há um excesso de modificação/adjetivação desse mesmo substantivo, mas com outros adjetivos - caso de "escravos negros"?

Para iniciarmos nossa análise dos significantes "escravo", "colono", "colonizador", "senhor-de-engenho", "imigrante", "branco", "negro", "africano", "europeu” e respectivas flexões, 
teorizemos brevemente sobre uma possibilidade de trabalho com córpus em Análise do Discurso.

\section{Léxico, córpus, arquivo e discurso}

A análise do discurso há décadas estabelece uma relação de observação, crítica e teorização sobre léxico, córpus e arquivo. Em 1981, Pêcheux advertia que "Um corpus de arquivo textual não é um 'banco de dados'" (PÊCHEUX, 2011 [1981]), precisamente por conta da não transparência, da não completude, da historicidade e da sujeição à interpretação dos arquivos. Recentemente, a linguística de córpus mesma tem assumido o compromisso com a negação de qualquer suposta completude dos corpora:

Como não se tenha uma medida da proporção de usos de textos e discursos em uma comunidade de falantes/escritores da língua, cada corpus passa a ter apenas uma pequena parte do total de amostras potenciais da língua. Por isso, temos que considerar o corpus como um fragmento de língua, mas que, mesmo assim, representa o seu sistema global (ou parte dele) e que, mesmo incompleto e fragmentado, pode refletir as possibilidades de ocorrência de usos linguísticos potenciais. (OLIVEIRA, 2009, p. 58)

No entanto, não trabalhamos sob o primado de que cada córpus componha um também suposto sistema. Em uma direção diferente, podemos afirmar que "O arquivo (...) joga com a fronteira entre a ilusão do tudo reunir e o reconhecimento do furo de que não é possível arrebanhar todos os campos de documentos sobre uma dada questão" (DELA-SILVA; LEANDRO-FERREIRA; SOUSA, 2012, p. 13). Portanto, cada arquivo projeta em si a ilusão de que é possível tudo reunir, mas contraditoriamente essa completude só se daria por escalonamento, por amostragem, por estatística, por potencialidades: no arquivo, a completude nunca é uma certeza, mas uma previsão e um desejo. Olhar para o Corpus do português, assim, requer uma desmistificação de qualquer pretensão de completude, de potencial de amostragem, de generalização a partir de dados. E demanda, também, uma historicização, com distintos aparatos, de sequências discursivas, de sintagmas nominais, de materialidades cuja memória se impõe diante do arquivo, mas que pode ser apagada com a ilusão de que ele 
funciona numa sincronia perene. Como nos lembra Nunes, “O material de arquivo está sujeito à interpretação" (NUNES, 2005, n.p.). Mas como interpretar analiticamente? Ainda retomando Dubois, "(...) a repartição das palavras num texto não é aleatória e implica um modelo subjacente, ideológico, do qual ela pode dar uma primeira ideia" (DUBOIS, 1994 [1969], p. 111). Selecionar as sequências de um córpus como o de Davies e Ferreira (2006) da posição de analista do discurso é olhar para essa repartição de palavras e dar conta de responder qual é sua filiação ideológica, quais os efeitos de evidência produzidos, como os discursos ali presentes reforçam ou combatem outros, regendo e determinando as práticas materiais numa formação social. No caso deste artigo, como vão se consolidando imagens de negros e brancos a partir do uso desses adjetivos - "negro", "branco" e flexões - em adjunção a nomes.

\section{Entrada no corpus}

Conforme já avisamos mais atrás, nossa pesquisa compreende um recorte do Corpus do português (DAVIES; FERREIRA, 2006), em que pesquisamos alguns sintagmas nominais circunscritos em documentos escritos no Brasil e em Portugal entre os séculos XVI e XX, e categorizados pelos autores como textos ficcionais, acadêmicos, noticiosos ou orais transcritos. Com as sequências selecionadas, montamos um arquivo discursivo que será interpretado de modo a relacionarmos as estruturas linguísticas "à sua determinação não linguística, às condições sócio-históricas - reduzidas a relações entre as classes sociais que se exprimem por meio de formações ideológicas" (BRANCA-ROSOFF, 2008, p. 134). Para isso, perseguiremos as repetições de adjetivos, as diferenças entre singular e plural, as ausências de adjetivação, o modo como cada entrada foi catalogada - entre texto de ficção, acadêmico, jornalístico e oral transcrito. Principalmente, compararemos o excesso de algumas adjetivações e a falta de outras. A partir desse funcionamento linguístico-textual chegaremos ao processo discursivo:

em primeiro lugar, a língua aparece a partir daí como a base do processo discursivo, ou seja, como aquilo que dá suporte ao processo, sem se o identificar: assim, o sistema lexical da língua, assim como o conjunto de regras sintáticas 
que são estudadas pela linguística, pré-existem a todo efeito discursivo, como base material desse processo. (GAYOT; PÊCHEUX, 1971, p. 687; tradução nossa) ${ }^{5}$

É na língua que vamos observar as filiações de sentido, a relação discurso-ideologia e a eficácia material do processo semântico. Comecemos pela própria combinação de "escravo" e distintos adjetivos, como "negro", "africano", "branco", "europeu" e flexões. Colamos a seguir o modo como o Corpus do português nos apresenta seus resultados.

\section{"escravo negro": 1 ocorrência}

\begin{tabular}{|l|l|l|}
\hline 1 & 19:Fic:Br:Novaes:Mao & $\begin{array}{l}\text {, uma habitação para afim de evitar contatos indesejáveis. Segundo, } \\
\text { outra para o escravo negro e sua companheira. Terceiro, a do casal } \\
\text { de índios. Quarto, }\end{array}$ \\
\hline
\end{tabular}

${ }^{5}$ No original: “(...) en premier lieu, la langue apparaît désormais comme la base du processus discursif c'est-à-dire comme ce qui supporte ce processus, sans s'identifier lui : ainsi, le système lexical de la langue, aussi bien que l'ensemble des règles à syntaxiques qui sont étudiées par la linguistique, préexistent à tout effet discursif, comme base matérielle de cet effet" (GAYOT \& PECCHEUX, 1971, p. 687).

Para fins de explicação, na segunda célula da tabela, iniciada por "19", esse número corresponde aos anos 1900 (século XX), "Fic" é abreviação de ficcional, "Br" significa publicado no Brasil, "Novaes" é o sobrenome do autor e "Mao" mostra as primeiras letras do título da publicação, quando sabida: nesse caso, o livro Mão de luva, de Paulo Novaes, publicado em 1996. Essa foi a única ocorrência em que encontramos "escravo negro" nessa forma, singular. No córpus pesquisado, não há nenhuma entrada da flexão singular antes da década de 1990. No entanto, a forma plural comparece 22 vezes: 21 no século XX, de modo equilibrado entre Brasil e Portugal - com algumas entradas também da década de 1990, segundo o chamado contexto ampliado do Corpus do português -, e uma no século XIX, em Portugal:

\section{"escravos negros": 22 ocorrências}

\begin{tabular}{|l|l|l|}
\hline 1 & $\begin{array}{l}\text { 19:Fic:Br:Lemos: } \\
\text { Espaco }\end{array}$ & $\begin{array}{l}\text { marginaliza-do, igual aos demais que trabalhavam feito mouro, sem } \\
\text { se diferençarem muito dos escravos negros. O que havia em tudo } \\
\text { aquilo era só interesses pessoais, como bem }\end{array}$ \\
\hline 2 & $\begin{array}{l}\text { 19:Fic:Br:Novaes: } \\
\text { Mao }\end{array}$ & $\begin{array}{l}\text { está o castelo? - Isso vamos construir. - Assustados, foram-se } \\
\text { perfilando cinco escravos negros desertores das bandas das } \\
\text { plantações de café do Ressaca. Mais uma escrava, }\end{array}$ \\
\hline 3 & $\begin{array}{l}\text { 19:Fic:Br:Queirós: } \\
\text { Muralha }\end{array}$ & $\begin{array}{l}\text { e Cristina se sentaram e foram atravessando, lado a lado, carregadas } \\
\text { por quatro escravos negros, a porteira da Fazenda. Do alto Cristina } \\
\text { viu o campo coberto de }\end{array}$ \\
\hline
\end{tabular}




\begin{tabular}{|c|c|c|}
\hline 4 & $\begin{array}{l}\text { 19:Fic:Br:Queirós: } \\
\text { Muralha }\end{array}$ & $\begin{array}{l}\text { nome Bento Coutinho, que se associara ao grupo. Tinha vendido } \\
\text { meia dúzia de escravos negros e uns vinte índios carijós, os quais } \\
\text { iam algemados atrás da tropa, }\end{array}$ \\
\hline 5 & 19Ac:Br:Enc & $\begin{array}{l}\text { do período colonial era, em maior parte, proveniente das atividades } \\
\text { de comércio de escravos negros que forçadamente migraram da } \\
\text { África. A força de trabalho dos negros africanos foi }\end{array}$ \\
\hline 6 & 19Ac:Br:Enc & $\begin{array}{l}\text { esses locais se tornaram palco da instalação de grandes latifúndios } \\
\text { agro-exportadores, tocados unicamente por escravos negros (a } \\
\text { população local fora dizimada durante o processo de ocupação). } \\
\text { Porém }\end{array}$ \\
\hline 7 & 19Ac:Br:Enc & $\begin{array}{l}\text { Valdívia funda a cidade de Santiago do Chile. } 1563 \text { - Chegada dos } \\
\text { primeiros } 300 \text { escravos negros às colônias britânicas da América do } \\
\text { Norte. } 1567 \text { - Fundação da cidade de }\end{array}$ \\
\hline 8 & 19Ac:Br:Lac:Thes & $\begin{array}{l}\text { assimilados uns após outros, parecia muito mais difícil assimilar ou } \\
\text { absorver os descendentes dos escravos negros. Os negros competiam } \\
\text { pelos mesmos empregos. Obtinham, porém, os empregos }\end{array}$ \\
\hline 9 & 19Ac:Br:Lac:Thes & $\begin{array}{l}\text {, sem dúvida nenhuma, dos elementos mais seletos e eugênicos na } \\
\text { formação brasileira com escravos negros e mulatos foi formidável. } \\
\text { Resultou daí grossa multidão de filhos ilegítimos, mulatinhos }\end{array}$ \\
\hline 10 & 19Or:Pt:Intrv:Pub & $\begin{array}{l}\text { uma forte marca negra, porque foi a zona do país com maior } \\
\text { percentagem de escravos negros. E embora hoje não se distinga } \\
\text { muito, tirando uma ou outra área }\end{array}$ \\
\hline 11 & $\begin{array}{l}\text { 19:Fic:Pt:Dantas: } \\
\text { Abelhas }\end{array}$ & $\begin{array}{l}\text { e de tijelas de mínio, copiando os portulanos trazidos de Veneza; } \\
\text { levas de escravos negros alastrara, corno rebanhos, na terra } \\
\text { escalvada; todo o ruído, toda }\end{array}$ \\
\hline 12 & 19Ac:Pt:Enc & $\begin{array}{l}\text { ). Toca-se com um plectro. O banjo teve a sua origem entre } \\
\text { os escravos negros do sul dos Estados Unidos e baseou-se num } \\
\text { instrumento muito semelhante, de origem }\end{array}$ \\
\hline 13 & 19Ac:Pt:Enc & $\begin{array}{l}\text { depois, com a vitória da união, essa situação se tornou real. } \\
\text { Os escravos negros, agora livres, eram considerados rivais } \\
\text { económicos pelos brancos pobres. Surgiram então }\end{array}$ \\
\hline 14 & 19Ac:Pt:Enc & $\begin{array}{l}\text { Segundo uma das versões, surgiu em } 1879 \text { e tem origem africana, } \\
\text { pois os escravos negros que vieram para a América trouxeram } \\
\text { consigo os seus costumes e, entre eles }\end{array}$ \\
\hline 15 & 19Ac:Pt:Enc & $\begin{array}{l}\text { e franceses fixaram-se no porto de Ouidah e transformaram-no } \\
\text { no maior centro de tráfico de escravos negros. Os portugueses } \\
\text { chegaram mesmo a construir uma fortaleza, em S. João }\end{array}$ \\
\hline 16 & 19Ac:Pt:Enc & $\begin{array}{l}\text { foi povoada a ilha do Fogo. A população era constituída por } \\
\text { brancos europeus e escravos negros oriundos da costa da Guiné. O } \\
\text { povoamento de outras ilhas decorreu no século }\end{array}$ \\
\hline 17 & 19Ac:Pt:Enc & $\begin{array}{l}\text { em que fazia saber que, a partir do início de } 1863 \text {, todos } \\
\text { os escravos negros pertencentes aos vários estados rebeldes, em luta } \\
\text { contra o governo federal, seriam }\end{array}$ \\
\hline
\end{tabular}




\begin{tabular}{|l|l|l|}
\hline 18 & 19Ac:Pt:Enc & $\begin{array}{l}\text { principal produto de exportação. O negócio tornou-se próspero } \\
\text { muito à custa do trabalho dos escravos negros trazidos do continente } \\
\text { africano. Em 1789, chegaram a ser quase 500 mil }\end{array}$ \\
\hline 19 & 19Ac:Pt:Enc & $\begin{array}{l}\text { O objectivo desta sociedade foi o de criar um local para onde } \\
\text { pudessem ir os escravos negros libertos do sul dos Estados Unidos. } \\
\text { Os primeiros ocupantes chegaram em 1822, }\end{array}$ \\
\hline 20 & 19Ac:Pt:Enc & $\begin{array}{l}\text { apresenta um curioso relevo com os escudos de armas da família } \\
\text { a ladear figuras de escravos negros, ocupados em actividades } \\
\text { relacionadas com a exploração do ouro na costa de África }\end{array}$ \\
\hline 21 & $\begin{array}{l}\text { 19Ac:Pt:Enc } \\
\text { XVI e XVIII, a Serra Leoa funcionou como um importante centro } \\
\text { de comércio de escravos negros. Em 1788, a Anti-Slavery Society } \\
\text { comprou a zona costeira aos autóctones. }\end{array}$ \\
\hline 22 & $\begin{array}{l}\text { 18:Herculano: } \\
\text { Bobo }\end{array}$ & $\begin{array}{l}\text { cativos nas frequentes correrias dos Leoneses, e cuja situação se } \\
\text { assemelhava à dos escravos negros da América, ou a cousa ainda } \\
\text { pior, dada a rudeza e ferocidade }\end{array}$ \\
\hline
\end{tabular}

Das 22 ocorrências acima, abramos um espaço específico para a primeira - que trata de um personagem ficcional, Albano Nuno Varela, um imigrante português branco no Brasil do livro Espaço terrestre (de Gilvan Lemos, 1993) -, e

para as últimas entradas - o romance oitocentista $O$ bobo, de Alexandre Herculano, em que, na sequência, ele trata de "sarracenos, mouros ou moçárabes, cativos nas frequentes correrias dos Leoneses" -, já num recorte nosso:

S3: igual aos demais que trabalhavam feito mouro, sem se diferençarem muito dos escravos negros.

S4: cuja situação se assemelhava à dos escravos negros da América, ou a cousa ainda pior, dada a rudeza e ferocidade

Interessante apontar que, se pensarmos historicamente, podemos notar que as comparações entre o regime de trabalho dos mouros e o dos escravizados são frequentes, percorrendo, nesse caso, um total de 150 anos em diferentes continentes: de 1843, ano de publicação de $O$ bobo, a 1993, ano de publicação de Espaço terrestre. Mas também vale ressaltar que, apesar de aproximados, o critério de comparação entre os regimes de trabalho é o dos escravizados, o que se materializa, nas S3 e S4, respectivamente, em "sem se diferençarem muito dos" e "se assemelhava à dos". É o trabalho dos escravos, adjetivados aí como "negros", que é parâmetro de exploração extrema. E estranha-se que outros sujeitos estejam determinados a serem 
explorados assim, mas se naturaliza que o limite dos maustratos se dê com os "negros".

Nessas ocorrências encontradas, ainda mais um recorte que marca um paralelismo lexical e semântico aparente, mas assimétrico, numa entrada enciclopédica que trata da formação de Cabo Verde, especificamente, da povoação da ilha de Santiago:

S5: A população era constituída por brancos europeus e escravos negros oriundos da costa da Guiné.

Colocados lado a lado, "brancos europeus" e "escravos negros" soam como um paralelismo textualmente competente, mas há um equívoco aí, algo que diz da incompletude da língua, do tudo não poder ser dito. Digamos, com muitas ressalvas, que "escravo" seja uma categoria profissional, e trabalhemos com as designações e adjetivações dos sujeitos:

\begin{tabular}{|c|c|c|c|}
\hline Designações & Cor da pele & Proveniência & Categoria profissional \\
\hline brancos europeus & "brancos" & "europeus" & - \\
\hline $\begin{array}{c}\text { escravos negros } \\
\text { oriundos da costa da } \\
\text { Guiné }\end{array}$ & "negros" & "oriundos da costa da & "escravos" \\
\hline
\end{tabular}

Algo já se coloca, nesse quadro, quanto ao cerne deste artigo. Se cor da pele, proveniência e "categoria profissional" são ditos em relação aos negros, por que apenas cor da pele e proveniência são ditos quanto aos brancos? Por que não dizer que, sim, são brancos europeus exploradores, senhores, colonizadores e o que mais puder designar sua, por assim dizer, categoria profissional? Infelizmente, por informações ausentes no Corpus do português, não podemos evocar aqui a data de publicação dessa sequência, tampouco em que registro impresso ela foi lançada. Apenas podemos informar que se trata do recorte de uma enciclopédia, e que é um gesto político, uma política de a língua significar sujeitos.

O processo discursivo engendrado em "escravo branco" e flexões já é bem diferente. Não se naturaliza o adjetivo. 


\section{"escravo branco": 1 ocorrência}

1 18:Alencar: , um homem de bem, que se enobrecesse com sua afeição; preferiu

Senhora um escravo branco; estava em seu direito, pagava com seu dinheiro, e pagava generosamente

\section{"escravos brancos": 1 ocorrência}

1 17:Coutinho: que a Inglaterra mesma fez cultivar as terras do continente da América

Economica setentrional por escravos brancos, vendendo aos plantadores aquêles réus

de crimes que eram condenados perpètuamente aos serviços públicos

As ocorrências com "escravo branco", no singular e no plural, são ambas de autores brasileiros, uma num texto ficcional, outra num texto acadêmico. A seguir, fizemos os recortes das sequências para melhor entendermos a produção de sentidos.

S6: Os sectários da opiniao contra o comércio do resgate dos escravos da costa da África deviam lembrar-se que a Inglaterra mesma fez cultivar as terras do continente da América setentrional por escravos brancos, vendendo aos plantadores aquêles réus de crimes que eram condenados perpètuamente aos serviços públicos [de José Joaquim da Cunha Azeredo Coutinho, Obras econômicas, 1790]

S7: A senhora teve o mau gosto de comprar um marido aviltado; aqui o tem como o desejou. Podia ter feito de um caráter, talvez gasto pela educação, um homem de bem, que se enobrecesse com sua afeição; preferiu um escravo branco; estava em seu direito, pagava com seu dinheiro, e pagava generosamente. Esse escravo aqui o tem; é seu marido, porém nada mais do que seu marido! [de José de Alencar, Senhora, 1875]

Na S6, tem-se uma argumentação escravagista favorável ao comércio do resgate dos escravos - sem adjetivação -, respondendo aos "sectários da opinião" que a própria América do Norte contou com mão de obra escrava branca. Mais uma vez, por ausência, "negro" significa, e há uma relação de valoração dupla: se na América do Norte houve a presenta de escravos brancos, por que não teria de haver, no Brasil, escravos [negros]? É necessário dizer "escravos brancos", e produz-se o efeito de sentido de que é mais aceitável haver escravos negros que escravos brancos. De modo similar funciona a 
S7, em que "escravo branco" é usado de modo irônico. O personagem que profere a fala se afirma um "escravo branco", um deslocamento, um efeito metafórico de "escravo [Ø]", sem adjetivação explícita, mas que provoca o efeito de "escravo negro" na formação discursiva donde se escreve. Na S7, o personagem branco brinca com a ideia de ser escravo. Brincar com essa condição, tão presente num Brasil de 1875, faz parte daquilo que é possível de ser dito.

Dando prosseguimento à nossa análise, pesquisamos "escravo africano" e flexões. A forma masculina singular apresentou, no Corpus do português, nove ocorrências, todas do livro As vítimas-algozes, de Joaquim Manuel de Macedo. Com essa repetição excessiva numa mesma obra literária, podemos ao menos afirmar que se trata de um sintagma que funciona basicamente como um nome próprio, como um nome de personagem ou de tipo social que também é retomado por "escravo crioulo" numa concatenação de sentidos sobre quem seria o escravo africano. Já a forma masculina plural, "escravos africanos", contabiliza 14 ocorrências: todas do século XX, com exceção de uma entrada do mesmo livro. As 13 demais, de acordo com o córpus, constituem textos enciclopédicos: duas em obras brasileiras, 11 em obras portuguesas:

\section{"escravos africanos": 14 ocorrências}

\begin{tabular}{|l|l|l|}
\hline 1 & 19Ac:Br:Enc & $\begin{array}{l}\text { de Deus", e condena a escravidão destes 1538 - Lopes Bixorda traz } \\
\text { os escravos africanos ao Brasil 1539 - Catequese das colônias passa para a } \\
\text { responsabilidade da Companhia de Jesus }\end{array}$ \\
\hline 2 & 19Ac:Br:Enc & $\begin{array}{l}\text { do rio Amazonas 1559 - Concedido o alvará régio para facilitar as } \\
\text { importações de escravos africanos ao Brasil 1560 - Vitória de Mem de Sá } \\
\text { sobre os franceses 1560 - Entrada }\end{array}$ \\
\hline 3 & 19Ac:Pt:Enc & $\begin{array}{l}\text { respeita à música erudita, é de referir a influência dos jesuítas e } \\
\text { dos escravos africanos na música ameríndia, durante o século XVI. O } \\
\text { primeiro grande compositor brasileiro foi }\end{array}$ \\
\hline 4 & 19Ac:Pt:Enc & $\begin{array}{l}\text { fonte de armazenamento e provisões para as plantações, sendo habitada } \\
\text { quase inteiramente por escravos africanos que utilizaram a terra } \\
\text { relativamente estéril de forma cooperativa. Os Codringtons terminaram o } \\
\text { arrendamento }\end{array}$ \\
\hline 5 & 19Ac:Pt:Enc & $\begin{array}{l}\text { A Baamas têm cerca de 299 mil habitantes (2004), descendentes } \\
\text { de escravos africanos. A capital do país é Nassau. O idioma oficial é o } \\
\text { inglês. }\end{array}$ \\
\hline
\end{tabular}




\begin{tabular}{|c|c|c|}
\hline 6 & 19Ac:Pt:Enc & $\begin{array}{l}\text { espanhóis estabeleceram-se nas ilhas, pensando que lá pudesse existir } \\
\text { ouro, e importaram escravos africanos, dado que os indígenas não } \\
\text { estavam aptos ao uso das armas, nem resistiram }\end{array}$ \\
\hline 7 & 19Ac:Pt:Enc & $\begin{array}{l}\text {, e criaram plantações de açúcar e outras culturas, recorrendo ao trabalho } \\
\text { dos escravos africanos. Em 1670, as Baamas foram cedidas ao duque de } \\
\text { Albemarle como uma colónia-donatária }\end{array}$ \\
\hline 8 & 19Ac:Pt:Enc & $\begin{array}{l}\text { ocorreu ao longo da história do arquipélago, entre os colonos portugueses } \\
\text { e os escravos africanos. A capital do país é Praia. Os idiomas falados Cabo } \\
\text { Verde são o }\end{array}$ \\
\hline 9 & 19Ac:Pt:Enc & $\begin{array}{l}\text { milhões e } 656 \text { mil habitantes (2004), maioritariamente negros, } \\
\text { descendentes de escravos africanos. A capital do país é Port-Au-Prince. O } \\
\text { francês e o crioulo haitiano são }\end{array}$ \\
\hline 10 & 19Ac:Pt:Enc & $\begin{array}{l}\text {, quase todos os nativos tinham sido mortos e a ilha estava povoada } \\
\text { com escravos africanos. No final do século XIX, a Jamaica possuía } 800 \\
\text { engenhos de açúcar e }\end{array}$ \\
\hline 11 & 19Ac:Pt:Enc & $\begin{array}{l}800 \text { engenhos de açúcar e mais de mil fazendas pecuárias. Os } 200 \\
\text { mil escravos africanos a trabalhar nessas explorações tornaram-se o } \\
\text { sustento de todas actividades económicas. Com a abolição }\end{array}$ \\
\hline 12 & 19Ac:Pt:Enc & $\begin{array}{l}\text { colonos franceses, que lhe deram o nome de Ile de France e } \\
\text { importaram escravos africanos para trabalhar nas plantações de açúcar. } \\
\text { Tomada pelos ingleses em } 1810 \text {, e formalmente }\end{array}$ \\
\hline 13 & 19Ac:Pt:Enc & $\begin{array}{l}\text { outros grupos étnicos africanos. No país vivem ainda alguns europeus } \\
\text { e descendentes de escravos africanos, retornados do Brasil. A capital do } \\
\text { Togo é Lomé, com cerca de }\end{array}$ \\
\hline 14 & $\begin{array}{l}\text { 18:Macedo: } \\
\text { Mulheres }\end{array}$ & $\begin{array}{l}\text {, porém, ainda a influência, maligna, mortífera, dos depósitos } \\
\text { de escravos africanos no centro da cidade, e, pois que o podia, Jerônimo } \\
\text { Lírio praticava }\end{array}$ \\
\hline
\end{tabular}

Vemos aí uma preocupação de o que o córpus categoriza como texto enciclopédico produzir sentidos não sobre a cor dos escravizados, mas sobre sua proveniência. Na S8, sequência extraída da entrada 8 acima, são paralelizados "colonos portugueses" e "escravos africanos". Nesse caso, o discurso sobre a escravidão não nos pareceu fazer, mas buscar uma ilusão de estabilidade de sentido:

S8: Em Cabo Verde habitam cerca de 415 mil pessoas (2004), predominantemente mestiças, devido à miscigenação que ocorreu ao longo da história do arquipélago, entre os colonos portugueses e os escravos africanos.

As flexões femininas de "escravo negro" e "escravo africano" não comparecem no córpus. Nenhuma forma 
de "escravo europeu" foi encontrada. Em uma busca pelo aparentemente paradoxal "escravo imigrante", esse sintagma também não constava. ${ }^{6}$

\section{O contraste entre cor, alguma cor e não cor}

Nesta seção, buscamos recuperar o que entendemos ser o verdadeiro contraste no arquivo que constituímos: a adjetivação ou não de "colono", "colonizador" e "senhor-de-engenho", bem como a impressionante pouca ocorrência absoluta desses nomes em relação a "escravo". Fizemos uma pesquisa desses nomes sem proceder à sua adjetivação para sabermos com que frequência esses sujeitos foram ditos no córpus.

\begin{tabular}{|c|c|}
\hline Designação & Ocorrências \\
\hline Colono & 101 \\
\hline Colonizador & 47 \\
\hline Senhor-de-engenho & 42 \\
\hline Escravo & 1186 \\
\hline
\end{tabular}

Na tabela acima, a primeira conclusão a que podemos chegar é que é assustadora a diferença numérica entre quanto o "escravo" é dito e quanto seus algozes são ditos. Nem todas as ocorrências das demais categorias somadas resultam no número de ocorrências de "escravo". E, ao mesmo tempo em que falar da escravidão muitas vezes dignifica e vocifera o sofrimento desses sujeitos explorados de todas as maneiras possíveis, mal falar de quem escravizou contribui para que a história vá se construindo como autocausal, ou mesmo como se o escravagismo tivesse sido uma casualidade espontânea dos Trópicos.

Parece-nos que, diante da tabela anterior, quanto mais efeitos de sentido de exploração e de violência, que podem ser provocados pelo modo como esses homens brancos são designados, menos frequência das designações. "Colono" é

${ }^{6}$ Apesar do aparente $\mathrm{p}$ a r a d oxo, u $\mathrm{ma}$ rápida procura numa ferramenta de busca mostra, atualmente, centenas de resultados para "escravoimigrante". formado morfologicamente sem sufixo que remeta a uma ação: em outras palavras, é derivado de "colônia". Diferentemente de "colonizador", que recebe um sufixo - "-ador", responsável pela formação de nomes de profissão - a partir do verbo "colonizar"; em outras palavras, um substantivo que preserva 
os efeitos de sentido de um verbo, efeitos de sentido de atividade de colonizar algo (um lugar) ou alguém. Já o sintagma "senhor-deengenho" produz efeitos de propriedade, de autoridade, graças tanto a "senhor" quanto a "engenho". Em termos de ocorrência absoluta, colono > colonizador $>$ senhor-de-engenho. Uma ocorrência que decresce na proporção inversa da evidência da violência no trato do escravizado: se a violência é mais evidente, a palavra mal comparece no córpus. E isso é, conforme temos dito, também uma política de língua.

Observemos agora, então, como esses itens lexicais e suas flexões são adjetivados. "Colono branco" não conta com nenhuma ocorrência, diferentemente de seu plural masculino, que recebe nove ocorrências, provocando o efeito - talvez positivo, dentro de um discurso escravagista ou a partir dele parafraseado - de que as colônias seriam brancas. Apenas uma dessas ocorrências é de um documento brasileiro, também categorizado como texto enciclopédico pelo córpus, e publicado no século XX. Trata-se de uma passagem de um artigo sobre a "Crise do Congo". Assim sendo, nesse córpus, não há qualquer publicação brasileira que materialize a forma "colonos brancos". Observando o contexto ampliado das entradas de documentos portugueses, também é possível perceber que não se fala de "colonos brancos" do Brasil. Fala-se de colonos brancos, principalmente britânicos (sete ocorrências), com uma ocorrência de "colonos brancos" na Ilha do Sal, Cabo Verde. Ao que nos parece, impõe-se, na língua portuguesa, uma grande dificuldade em falar da cor dos colonos, principalmente quando eles são lusitanos.

Já não há um silenciamento tão patente da nacionalidade/ proveniência dos colonos: apesar de não haver ocorrência de "colono português", há duas de "colonos portugueses", ambas em documentos do português europeu. Algo similar com "colono europeu": nenhuma ocorrência no singular, mas sete ocorrências no plural, nenhuma delas significando a colonização do Brasil.

Nosso arquivo torna-se mais contrastivo ainda nesse ponto, quando cotejamos "escravo negro" e flexões com "colonizador branco" / "senhor-de-engenho" e flexões. Simplesmente não há nenhuma ocorrência de nenhuma flexão de "colonizador branco" nem de "senhor-de-engenho". Por que identificar a cor do escravizado e não identificar a cor 
do escravizador e do senhor-de-engenho? Por que saturar os sentidos de um nome e não de outro? Se escravizado tem cor, quem o explora ou explorou não é incolor. Um furo, no entanto, se inscreve. Pálida e cegamente, mas se inscreve. Há sete ocorrências de "colonizadores europeus", algumas delas com denúncias da violência do europeu contra as terras e povos que colonizaram ou tentaram colonizar. Mas falar "europeu" não é sempre o mesmo que falar "branco".

\section{Da imigração incolor}

Se nas designações de escravizados e seus algozes há alguma oscilação na presença de adjetivação dos substantivos, no nome "imigrante" há quase uma total ausência de adjetivos referindo-se à cor dessa categoria. A única ocorrência que encontramos no Corpus do português foi de "imigrante branco", no singular, não tendo sido localizada qualquer entrada no feminino e/ou no plural:

\section{"Imigrante branco": 1 ocorrência}

$1 \quad$ 19Ac:Br:Lac:Thes de tudo amenizar os danos causados ao país pela presença do negro, já o imigrante branco europeu era a marca de civilização e progresso. Para Tavares Bastos (1839-1875

Repare-se que "branco", nesse caso, vem acompanhado de outro adjetivo: "europeu". No entanto, opõem-se acima "presença do negro" - causadora de "danos" - e "imigrante branco europeu" - "marca de civilização e progresso". Ainda que, num contexto ampliado, seja possível concluir que não se trata de posições assumidas ou defendidas pelo texto, sua presença nele materializa a circulação desses discursos na formação social brasileira. E não nos esqueçamos de como já se está falando do negro: "presença do negro", o que até certo ponto apaga a violência da escravidão.

Conforme poderemos mostrar à frente, para se falar de imigração, focaliza-se muito mais a proveniência do imigrante que sua cor. Apesar de não haver ocorrência de "imigrante europeu", sua flexão plural rende uma boa frequência: 


\section{“Imigrantes europeus": 8 ocorrências}

\begin{tabular}{|c|c|c|}
\hline 1 & $\begin{array}{l}\text { 19:Fic:Br: } \\
\text { Amado:Terras }\end{array}$ & $\begin{array}{l}\text { de Itabuna. Aranha-canaa.txt\#\# Milkau, alemão, recém-chegado, o a } \\
\text { uma colônia de imigrantes europeus, no Espírito Santo, aluga um cavalo } \\
\text { para ir do Queimado à cidade }\end{array}$ \\
\hline 2 & 19Ac:Br:Enc & $\begin{array}{l}\text { de tal evento. Tratava-se de uma próspera cidade, que recebia grande } \\
\text { número de imigrantes europeus e modernizava-se rapidamente, com a } \\
\text { implantação de indústrias e reurbanização. Era, }\end{array}$ \\
\hline 3 & 19Ac:Br:Enc & $\begin{array}{l}\text {, o território do atual Estado de Santa Catarina passou a receber novas } \\
\text { levas de imigrantes europeus: italianos e sobretudo alemães passaram a } \\
\text { fixar-se na região. Os alemães têm }\end{array}$ \\
\hline 4 & 19Ac:Br:Enc & $\begin{array}{l}\text { metodologia próprios. Em um país relativamente jovem, cuja porção } \\
\text { letrada era formada por imigrantes europeus e seus descendentes, a } \\
\text { filosofia em nosso país foi, em sua quase }\end{array}$ \\
\hline 5 & 19Ac:Br:Enc & $\begin{array}{l}\text {. A classe operária ganhava novas forças, anteriormente de feições } \\
\text { anarquistas e formada por imigrantes europeus que possuíam alguma } \\
\text { experiência em movimentos reivindicatórios. Assumindo interinamente } \\
\text { o governo, Delfim }\end{array}$ \\
\hline 6 & $\begin{array}{l}\text { 19Ac:Br:Lac: } \\
\text { Thes }\end{array}$ & $\begin{array}{l}\text { urgente da mão-de-obra livre, para atuar na área cafeeira. Outros já } \\
\text { viam nos imigrantes europeus a possibilidade de renovar a população } \\
\text { brasileira, como foi o caso de Tavares }\end{array}$ \\
\hline 7 & $\begin{array}{l}\text { 19Ac:Br:Lac: } \\
\text { Thes }\end{array}$ & $\begin{array}{l}\text { 1932, cria o movimento integralista em São Paulo, o estado que mais } \\
\text { recebeu imigrantes europeus. Esse movimento tinha sustentação na } \\
\text { classe média urbana, entre os operários e }\end{array}$ \\
\hline 8 & 19Ac:Pt:Enc & $\begin{array}{l}\text { Paulo e Minas Gerais. Por essa altura tinham chegado ao Brasil } 3 \text { milhões } \\
\text { de imigrantes } \underline{\text { europeus que se haviam fixado junto à costa. Depois de }} \\
\text { um período de agitação }\end{array}$ \\
\hline
\end{tabular}

Das oito ocorrências acima, sete estão presentes em textos brasileiros, para falar do povoamento do Brasil por imigrantes no século XX. Na oitava ocorrência, um texto português que também trata da presença de imigrantes europeus na excolônia das Américas. Comparando a esses resultados, não há nenhuma ocorrência de "imigrante negro" em nenhuma flexão, mas quatro ocorrências de "imigrante africano" em distintas formas:

\section{"imigrantes africanos": 3 ocorrências}

$1 \quad$ 19N:Pt:Expr origem, para a qual o MAI tem disponível 30 mil contos. \#

Os imigrantes africanos em Portugal serão um dos temas em debate nas « Jornadas contra o Racismo» 


\begin{tabular}{|l|l|l|}
\hline 2 & $\begin{array}{l}\text { 19N:Pt: } \\
\text { Público }\end{array}$ & $\begin{array}{l}\text { estava indefinida a propriedade de os edifícios, grande parte de eles foram } \\
\text { ocupados por imigrantes africanos. Em } 9 \text { de Abril último, o tribunal de } \\
\text { Vila Franca iniciava acções }\end{array}$ \\
\hline 3 & $\begin{array}{l}\text { 19N:Pt: } \\
\text { Público }\end{array}$ & $\begin{array}{l}\text { ainda críticas a o Governo português, por não ter tomado medidas para } \\
\text { que os imigrantes africanos tivessem melhores condições de vida, antes de } \\
\text { tratar de a sua legalização. }\end{array}$ \\
\hline
\end{tabular}

\section{“imigrante africana": 1 ocorrência}

\begin{tabular}{|l|l|l|}
\hline 1 & $\begin{array}{l}\text { 19N:Pt: } \\
\text { Público }\end{array}$ & $\begin{array}{l}\text { Indignados com a ausência de negros em lugares elegíveis, os } \\
\text { representantes de a comunidade imigrante africana aconselharam o voto } \\
\text { em branco. Fernando Ká, } 41 \text { anos, presidente de }\end{array}$ \\
\hline
\end{tabular}

7 Lembramos que a motivação para a recepção d e imigrantes no Brasil nunca foi exatamente homogênea. Muitos imigrantes brancos e europeus chegaram a o país também fugindo de tragédias, de perseguições políticas, de condições de vida precárias etc, e continuaram a ser designados "imigrantes", ainda que em condição análoga à categoria legal contemporânea de "refugiado", sobre a qual não comentaremos profundamente neste artigo, pois já figura em trabalhos riquíssimos desenvolvidos ou em desenvolvimento por outros pesquisadores.
Note-se da improbabilidade de se falar, no referido córpus, de imigrantes negros, e se fala de imigrantes africanos apenas em Portugal, enquanto, no Brasil, o sintagma "imigrante europeu" é vencedor, ainda reservando uma ocorrência para "imigrante branco". É como se não houvesse imigrantes negros e africanos no Brasil. É como se a condição de imigrante fosse muitíssimo distinta de outras, e como se o negro e o africano só tivessem entrado no Brasil como escravizados ou como refugiados. ${ }^{7}$

Daí que, ao se falar de "imigrante", é possível que se imagine um "branco" e/ou um "europeu", a não ser que se o adjetive como "negro" e/ou "africano". E, ao se falar de um "escravo", imagina-se um "negro" - muitas vezes, infelizmente o contrário também é válido. Duma perspectiva próxima à nossa, a da semântica do acontecimento, Guimarães (2016, p. 135) afirma, após análise das categorias de "cidadão", "súdito", "escravo" e "brasileiro" em documentos legais do século XIX, que

ser brasileiro é determinado por cidadão e, portanto, o escravo nascido no Brasil não é brasileiro, porque não é cidadão, não é súdito (...). Eles estão excluídos da cidadania, da qualidade de ser brasileiro e não pertencem, assim, ao espaço sócio-histórico em que nasceram e vivem. (GUIMARÃES, 2016, p. 135)

O que tentamos demonstrar, neste artigo, é como o referente discursivo negro vai ganhando determinados sentidos, como o de ser (ex-)escravo, e como também vai sendo cerceado de outros, como o de ser imigrante no Brasil, por uma política 
de significá-lo na língua. Na sequência, Guimarães (2016, p. 138) ainda afirma que preto será também uma designação sinônima de escravo, e aqui vemos que também negro funciona do mesmo modo.

Voltamos aqui então à Encyclopédia popular mencionada no início deste artigo, no intuito de exibir como o processo discursivo que temos investigado vai para além do arquivo que montamos a partir do Corpus do português. Negro e escravo vão sendo discursivizados como um mesmo referente já no século XIX. Leiamos o que se diz na nota biográfica de José Bonifácio presente na enciclopédia:

S9: Cultivou a litteratura e a poesia; aprofundou as sciencias naturaes, e publicou diversas memórias, sendo algumas dellas sobre os indios e escravos no Brazil. (VEIGA, 1879, p. 592)

Ao negro é reservado o lugar de ser escravo, tanto que "escravo" é paralelizado ao significante "índio", que produz efeitos de sentido de povo, de etnia e de cor. "Escravo", fatalmente, também. Subalternizar o negro na língua em que ele se constitui é uma política de língua, uma vez que, através dessa base material do discurso, os lugares sociais são pré-determinados e reproduzidos. Ao mesmo tempo, desresponsabilizar o branco por seu agenciamento da colonização, como colono, colonizador ou senhor-de-engenho (em diferentes proporções, como vimos mais atrás), também é um gesto político de língua, pois o mesmo branco não é significado, nessa língua, como a cor responsável pelo escravagismo, como a cor que fazia outra cor ser serviçal a ela.

\section{Abrindo caminhos: políticas e tomadas de posição na língua}

Uma das limitações que encontramos neste artigo foi o debruçar-se sobre um arquivo restrito e que projeta a ilusão de abranger documentos anteriores ao século XIX. Ao que notamos, o Corpus do português foi construído com muito mais documentos dos séculos XIX e XX, até por conta da maior facilidade de acesso a textos já digitalizados a partir de 1900. Assim, nos foi impossível saber se os funcionamentos discursivos que identificamos se davam também em 
documentos anteriores a 1790 (que foi o mais antigo que encontramos). É claro que isso não é exatamente um problema: um problema seria se tivéssemos considerado nosso arquivo completo e homogêneo, o que esperamos não ter feito.

Pêcheux (2011 [1976], p. 236) teceu diversas críticas ao funcionamento das ciências humanas e sociais nas universidades, sobretudo em relação à serventia das pesquisas universitárias ao poder do Capital, ainda que incauta e insabidamente. Para nós, cabe também à análise do discurso não apenas investigar os efeitos de sentido que têm sido produzidos nesse dispositivo que é o registro escrito - em que o discurso acadêmico está inserido -, mas também apontar para o que não se registra, para caminhos e trajetos que poderiam ter feito face ao poder (do Capital), mas não foram. Tomadas de posição na língua com potencial de significar e ressignificar sujeitos.

Assim, a investigação / crítica deste artigo vai no sentido final de questionar o que a academia, nos registros escrito e oral, pode fazer também como política de língua, de modo a historicizar e ressignificar o lugar dos sujeitos na formação social brasileira. Como a academia pode explicitar o silenciado, o que poderia ter sido, mas não foi. Talvez caiba a ela demonstrar que é necessário adjetivar o colono, o colonizador e o senhor-deengenho. Foram (são) brancos. Colonos brancos, colonizadores brancos e senhores-de-engenho brancos, que escravizaram, estupraram, violentaram, exploraram, traficaram, enganaram, humilharam, assassinaram negros... e índios. E que, enquanto não forem historicizados pelo lugar incolor que foram construindo na língua, continuarão escravizando, estuprando, violentando, explorando, traficando, enganando e humilhando, por sua dominância na formação social brasileira. $\mathrm{O}$ branco é invisível no regime escravocrata brasileiro. Se é possível que o significante "negro", hoje, produza efeitos de sentido que relacionem o sujeito assim designado ou predicado como subalterno, como explorado, carece expor quem o subalternizou e o explorou. Questão de política linguística. Questão de tomada de posição - inconsciente, e não menos política ao dizer, ao tomar a palavra, ao adjetivar ou não. Ao dar cor, textura e visibilidade à exploração silenciada. 


\section{REFERÊNCIAS}

AUTHIER-REVUZ, J. Falta do dizer, dizer da falta: as palavras do silêncio. Trad.: Maria Onice Payer. ORLANDI, E.P. (org.). Gestos de leitora: da história no discurso. Campinas: Editora da Unicamp, 1994.

BRANCA-ROSOFF, S. Formação discursiva: uma noção excessivamente ambígua?

BARONAS, R.L.; KOMESU, F. (orgs.). Homenagem a Michel Pêcheux: 25 anos de presença na análise do discurso. Trad.: Roberto Leiser Baronas, Dilson Ferreira da Cruz, Fabiana Komesu. Campinas: Mercado de Letras: 2008.

CERTEAU, M. de; DOMINIQUE, J.; REVEL, J. Une Politique de la langue. Paris: Gallimard, 2002 [1975].

DAVIES, M.; FERREIRA, Michael. Corpus do Português: 45 million words, 1300s-1900s. 2006. Disponível em: http://www. corpusdoportugues.org e http://corpus.byu.edu/cdp/x.asp.

DELA-SILVA, S.; LEANDRO-FERREIRA, M.C.; SOUSA, L.M.A. e. Arquivo. In: MARIANI, B.; MEDEIROS, V.; DELA-SILVA, S. (orgs.). Discurso, arquivo e... Rio de Janeiro: 7Letras, 2011.

DUBOIS, J. Lexicologia e análise do enunciado [1969]. Trad.: Pedro de Souza. ORLANDI, E.P. (org.). Gestos de leitora: da história no discurso. Campinas: Editora da Unicamp, 1994.

GAYOT, G.; PÊCHEUX, M. Recherches sur le discours illuministe au XVIIIe siècle : Louis-Claude de Saint-Martin et les « circonstances ». Annales. Économies, Sociétés, Civilisations. p. 681-704. 26e année, n. 3-4, 1971.

GUIMARÃES, E. A não igualdade dos não ingênuos: sobre escravos e cidadãos no século XIX no Brasil. FONSECA, Rodrigo Oliveira (org.). A Conjuração Baiana e os desafios da igualdade no Brasil: história e discurso. São Carlos: Pedro \& João Editores, 2016.

NUNES, J.H. Leitura de arquivo: historicidade e compreensão. Anais do II SEAD - Seminário de Estudos em Análise do Discurso. Porto Alegre: UFRGS, 2005.

OLIVEIRA, L.P. de. Linguística de corpus: teoria, interfaces e aplicações. Matraga, v. 16, n. 24. Rio de Janeiro: UERJ, jan./ jun. 2009. 
ORLANDI, E. Lingua e conhecimento linguístico: Para uma História das Ideias Linguísticas no Brasil. São Paulo: Cortez, 2002.

PÊCHEUX, M. Análise de discurso e informática [1981]. Trad.: Cristiane Dias. Análise de discurso: Textos escolhidos por Eni Puccinelli Orlandi. Campinas: Pontes, 2011.

. Posição sindical e tomada de partido nas ciências humanas e sociais [1976]. Trad.: Lauro Baldini. Análise de discurso: Textos escolhidos por Eni Puccinelli Orlandi. Campinas: Pontes, 2011.

. Semântica e discurso: uma crítica à afirmação do óbvio. 4. ed. Trad.: Eni Orlandi et alii. Campinas: Editora da Unicamp, 2009 [1975].

VEIGA, B.S. da (ed.). Encyclopedia popular. Campanha, MG: Typographia do <<Monitor Sul-Mineiro >> de Bernardo Saturnino da Veiga, 1879. 


\section{Abstract \\ On the (im)probability of being an immigrant: a discursive reading of "black" and "white" in noun phrases in a Portuguese corpus}

In this article, inscribed in materialistic Discourse Analysis (Pêcheux), we intend to investigate how the status of "immigrant" in Brazil has being built by the language spoken in the country, allowing some to be designated by this noun and forbidding others. To do so, we zoomed in the oppositions / complementarities / combinations of the nouns "slave", "settler", "colonizer", "mill boss", "immigrant" with the adjectives "white", "black", "African", "European" and its grammatical variations, by searching them in the very first version of the Corpus do Português, edited by the researchers Mark Davies and Michael J. Ferreira. On one hand, it was necessary to also think through how Discourse Analysis can articulate itself with Corpus Linguistics. On the other hand, we could come to fruitful conclusions that do not remit directly to immigration, but that say too much about how settlers, colonizers and mill bosses are meant in distinct materialities.

Keywords: Ethnic-racial issues. Slavery. Immigration. Discourse. Politics. 